\title{
Challenges to Learners in Interpreting Self as Other, Post COVID-19
}

\author{
Carol Nash
}

check for

updates

Citation: Nash, C. Challenges to Learners in Interpreting Self as Other, Post COVID-19. Challenges 2021, 12, 31. https://doi.org/10.3390/ challe12020031

Academic Editor: Susan L. Prescott

Received: 4 September 2021

Accepted: 16 November 2021

Published: 18 November 2021

Publisher's Note: MDPI stays neutral with regard to jurisdictional claims in published maps and institutional affiliations.

Copyright: (C) 2021 by the author. Licensee MDPI, Basel, Switzerland. This article is an open access article distributed under the terms and conditions of the Creative Commons Attribution (CC BY) license (https:// creativecommons.org/licenses/by/ $4.0 /)$.
History of Medicine Program, Department of Psychiatry, Temerty Faculty of Medicine, University of Toronto, Toronto, ON M5S 1A1, Canada; carol.nash@utoronto.ca

\begin{abstract}
The COVID-19 pandemic has prompted continuing constraints on the ability of students to interact with teachers and peers. Regarding this imposed segregation, what has not been considered is the effect of learners seeing self as other. With respect to augmentations of their body in interpersonal space by, (1) extending the body through witnessing themselves regularly in videoconferencing learning sessions, (2) isolating the body as a result of spending time apart from peers, social distancing at home, and (3) protecting the body through required mask-wearing where learners now consider who they represent in a mask, there are three important ways in which learners have felt unable to recognize themselves as they did pre-COVID-19. This migration from self to other, involving ingroup/outgroup distinctions, will be investigated from a number of perspectives-both sociological and psychological. Why the turning of self into other is problematic to the psyche will be discussed, as will the possible consequences for this ongoing lack of learner recognition long term, including focus on the new norms or embracing self-directed learning. Based on this analysis, the type of mentorship by teachers and parents that may be appropriate for helping learners contend with these changes will be recommended.
\end{abstract}

Keywords: COVID-19; self-other; interpersonal space; videoconferencing; social distancing; mask-wearing; ingroup/outgroup; self-directed learning; mentorship

\section{Introduction}

COVID-19 is the novel coronavirus disease of 2019 caused by the SARS-CoV-2 [1] virus, named by the World Health Organization on 11 February 2020 [2]. The pandemic associated with it was declared on 11 March 2020 [3] and is still ongoing [4,5]. The worldwide response to allay this threat has been organized and wide-ranging [6], yet the reaction has included discrimination and violence against marginalized groups [7]. Some of these targeted attacks have converted those with a previously intact sense of self to questioning their now diminished status in society [8] and wondering about their own blameworthiness for the devaluation, creating fear, anxiety, depression and avoidance behavior [9]. As such, these attacks have created, reinforced and reproduced positions of domination and subordination [10]. Othering is a process where the norm identifies and names those thought different from the self [11], stratifying identities into ingroup and outgroups [12]. Learners, by definition, are those people in positions of subordination within the ingroup of the socially accepted norm - a norm that is reinforced by their teachers, parents and more accomplished peers [13]. As feeling a need to see oneself as other in relation to the ingroup entails a lack of self-compassion [14], personal disconnection [15] and an inability to access and act on what is subjectively important to the self in the context of the ingroup [16], this problem of converting self into other with respect to COVID-19 limitations-for learners in particular-needs examination for the possible long-term consequences.

\subsection{Self and the Body}

Human identification with the self originates from an intimate connection with the body [17], extending in classical proxemic theory from intimate space to personal space, then to social space and finally, to public space [18]. The more complex and sophisticated 
the medical and technological enhancements of the body, the more insecure people become in understanding the distinction between self and other [19] within this space, tending to see self as other. Thus, any increase in artificial enhancements to the body within space, reducing access to the body's sensations, will cause a decrease in clear body identity with self. In this regard, "self" is defined as what the individual recognizes, acts on and feels responsible for with respect to what their body represents in society [20] and "other", in contrast, is what the individual does not recognize, act on or feel responsible for regarding what their body represents in society. With both alternatives, the individual need not be conscious of making this self-other distinction-it is their body's actions that are pertinent [21]. This is a result of the body being more than just a thing in the world-it is that which originates and defines the world of each individual [22].

COVID-19 has brought with it various medical and technological enhancements to decrease mortality and morbidity with respect to the virus. Those that represent an extension, modification and/or enhancement to an individual's body to permit it to function as required in a particular environment can be considered body augmentations [23]. There have been a number of body augmentations introduced in this regard. These include, but are not limited to, the following that either change the body itself or the protective space around it: wearing masks, social distancing, online communication (to be discussed and referenced to follow), vaccinations [24,25], sanitizing surfaces [26,27], curb-side pickup [28], and eschewing hair and nail salons [29]. With each of these body augmentations, body identity has been questioned by the individual in relation to the ingroup-defined as those members of a particular society permitted the power and norms to make and enforce social sanctions [30] - sometimes leading to assessments of self as other. As such, what is at issue is the psychologically and socially constructed dividing line between self and other presupposed before the recognition of any empathetic feelings of particular individuals in understanding the experiences related to other-oriented social emotion [31]. For this reason, a discussion of empathy will not be part of this examination of the self/other distinction. The aim of the discussion will be to identify under what conditions an understanding of self might cross that dividing line to become other, particularly as a consequence of COVID-19.

COVID-19, as a unique and potentially dire threat, is in itself a traumatic stressor to the body [32-34]. As such, the fear of COVID and of treatment by others if marginalized [35] are other aspects affronting identity resilience leading to identity change, where actual systemic issues remain neglected or ignored [36]. Fear is an additional consideration in the migration from imagining self to becoming other during the pandemic. The result of these body augmentations and traumatic stress in its various forms is that the sense of self has been altered in ways that may have long-term consequences, psychologically [37], socially $[38,39]$ and with respect to overall health [40].

Required to interact closely with others regardless of their consent, school children have been disproportionately affected by this change in how their body interacts with the world as a result of limitations imposed by school responses to the pandemic [41]. Thus, their sense of self has been disrupted by COVID-19 in a manner that differs from what they can normally expect from merely growing up and experiencing the changes to their body brought on by this usually uncontrollable development [42]. In their process of maturation, there are mentors available to students in their teachers, parents and peers for how they should respond to the changes to self they experience from growing up [43,44]. In contrast, given the uniqueness of the virus, there are no mentors for how to differentiate self from other as a result of the body disassociation brought on by COVID-19, and anxiety in caretaking adults with respect to this unknown can influence children's behavior in detrimental ways [45]. Although the scientific model employed by healthcare providers (among others who base their work on scientific findings) of continually updating their knowledge in relation to new information works well for advancing the science related to COVID-19, its shifting nature is not a model that permits students to find a firm foundation for the distinction between self and other [46]. Consequently, not only are students lacking advice on how to interpret the self during the pandemic, the information that they act 
on from scientific studies becomes concerningly unreliable as it is expected to change relatively quickly. Communicating the uncertainty of scientific facts to learners so that it can be positively processed by them regarding the self is challenging [47].

Students' experiences of the changes demanded of self as a result of imposed COVID-19 limitations can be examined through three categories of body augmentations that have been imposed as a result of COVID-19: extending the self, isolating the self, and protecting the self. These categories correspond to the different levels of space (from those that are most distant to those that are closest to intimate space) and will be investigated through the example of the body augmentation that has arguably had the greatest effect on students in each of the three cases-videoconferencing, social distancing and wearing masks. These three different ways of augmenting the body will be considered with respect to how they create the entanglement of self as other in response to the pandemic. The discussion to follow will elucidate the ways in which students' understanding of self has been altered. With the result of this assessment, parents and teachers can become better able to provide mentorship to students regarding what they can expect in now seeing self as other through their encounter with COVID-19, with the aim of diminishing possible long-term psychological, social and physical consequences. This assessment is to be based on distinctions in the foundational relationship between self and other as seen through various theories of self in society.

\subsection{Theories of Self and Other}

The ability to integrate and distinguish between representations of self and other is a necessary prerequisite for high-order social cognition fundamental to understand the intentions of others as differing from one's own [48]. Self-other representations are also important for developing episodic memory [49] where the sense of ownership becomes an essential aspect of human cognition, with self-ownership bias recognizable at multiple levels of behavior [50]. The identification of self in comparison with other relates to authorship of actions. A person is "self-alienated" if they consider something they did incompatible with their personal identify. In the case of such self-alienation, people recognize themselves as other in not being "true to themselves" [51]. It is in this type of self-alienation that the understanding of self then crosses the boundary into the realm of other. The understanding of the distinction between self and other is a social cognitive process depending on the inferred mental state of other people.

There are five levels to what is recognized as the self [52]. The first is that which identifies sensory signals. The second controls personal behavior during social interactions. Third is the autobiographical self, while fourth is the private self. The fifth level of self is the conceptual self, related to sociocultural experience. This social mentalizing is an evolutionary younger function responsible for switching one's perspective to unobservable mental states of another and encoding this information at a more abstract level in the form of personality traits through autobiographies, indicating the type of person someone sees themselves as being [53]. It is, therefore, in considering self as a multidimensional concept that the social impact of COVID-19 is to be interpreted.

\subsubsection{Self-Categorization Theory}

Self-Categorization Theory (SCT) [54] concerns the relationship between the self as individual and as part of the collective in differentiating from other. The theory examines group-level processes in terms of self-concept while assuming that group processes reciprocally mediate both self-categorization and cognition. As such, what people see as making themselves unique relates to both individual differences from other and to how individuals define themselves as members of certain social categories. Self identifies both what is labelled " $\mathrm{I}$ " and that which is defined as "we". What matters in any particular instance is the level of comparison and self-categorization that is taking place and the subjective sense of self that results - that is, whether the perceiver is defining the self as an individual person or as a member of a social group [55]. Social identity tends to become 
more evident in defining self within intergroup contexts, while personal identity takes the forefront in self-definition in intragroup contexts [56]. When self-categorization is interrupted or challenged either neurologically or behaviorally-as with COVID-19-the self is left identifiable as other, affecting the ability to project into one's future and in recalling the autobiographical past [57].

\subsubsection{Social Identity Theory}

In Social Identity Theory (SIT) [58], individuals define themselves in terms of group memberships and seek to maintain their self-identity through association with what they value in belonging to a group through comparison with other groups. In intergroup settings, individuals judge and enhance differences among groups in a way to favor the ingroup [59]. Positive self-identity from this perspective thus necessitates bolstering ingroups, whether or not the self is accepted as part of the ingroup or othered. Being part of the ingroup, in this theory, is necessary to create a positive self-concept. Yet, once the ingroup is defined, it is protected, even at the expense of depressed self-esteem as a result of being othered by the judgement of the ingroup [60]. With respect to COVID-19, the ingroup can be defined in various ways depending on the sense of what is important to self. In this way, not attending indoor religious gatherings, for example, could either be a requirement of the ingroup (for those who accept that the virus is spread through vocal spray) or the outgroup (in the case of those who see this restriction as a limitation to religious freedom). When considered from the perspective of the ingroup avoiding indoor religious gatherings, a parishioner could uphold this group as the norm yet be unable to abide by it personally because they have no other way of continuing their religious experience (e.g., lacking internet and having poor outdoor conditions for meeting). Such an individual, in going against the norm by continuing to attend indoor religious meetings, would have a depressed self-esteem and recognize themselves as other in relation to the ingroup as considered by SIT.

\subsubsection{Identity Process Theory}

Identity Process Theory (IPT) [61] focuses on the strategies people use to cope with threats, proposing that people strive to achieve an identity configuration of self-esteem, self-efficacy, personal continuity and positive distinctiveness. Recently IPT has focused on identity resilience [62]. This is a stable sense of self related to: an ability to understand and overcome problems, self-worth, value, and continuity in the world as other things change in the face of threats. Identity resilience has been found to predict both the fear of COVID-19 and feeling afraid when COVID-19 is the focus of thought. People most afraid of COVID-19 report the greatest amount of identity change, with the data suggesting that being emotionally aroused stimulates feelings of identity change [63] and of no longer recognizing the self. Identity change corresponds to feeling afraid, uncertain or mistrustful [64]. It is unclear if these changes to self, brought on by fear, result in long-term changes or they are merely a temporary phenomenon. Such changes are associated with increases in anxiety and depression if COVID-19 is actually contracted [65].

\subsubsection{Social Dominance Theory}

Social Dominance Theory (SDT) [66] contends that members of subordinate groups who have a desire to maintain status hierarchies coordinate with those who are dominant to retain the asymmetrical relationships. The reason is that, by doing so, they may assent in the hierarchy [67]. To permit their envisioned elevation through the ranks, subordinates must create prejudice and discrimination against low-power groups and individuals [68]. As such, othering is a systemic problem and is one continuously encountered by learners in relation to their parents, their teachers and older and/or more competent peers. Each of these with whom the learner comes in contact have social power-defined as the ability to influence others' beliefs, attitudes and behaviors [69] - and this social power limits and directs the learner in understanding self and determining when self should be considered other. 


\subsubsection{Self/Other Relationship}

Although the self originates with body sensations, it is not merely a result of the individual's own interpretation of those perceptions. Identifying the self also requires an understanding of ingroup and outgroup distinctions. The body's perceptions are then evaluated in relation to the views of the ingroup. Schooling is engaged with teaching learners what represents the norm [70,71] — the ingroup with which they should identify. Some learners may be adept and able to emulate the rules and procedures demanded by the ingroup. These learners have an intact sense of self and hold a belief that the world is fair [72]. Other learners anticipate that, with maturation and practice, they will gain advancement as part of the ingroup. These learners are permitted only subordinate roles in the ingroup by the norm, but they are still positively connected to valuing themselves in relation to the ingroup with respect to their role of actively discriminating against outgroups [73]. There are some learners, however, who are judged by the ingroup to be members of an outgroup. These learners still recognize the ingroup as defining the norm. As such, they are identified, and acknowledge themselves, as other. In this way, they are less than subordinate in relation to the ingroup. Through explicit derogatory language [74], they are socially isolated, feared and/or hated by the ingroup and tend to feel similarly about themselves [75]. In any case, the aim is to keep these individuals away from the ingroup and the privileges available to its members as the norm [76]. Those who are othered in this way see the world as an unjust place based on harsh social attitudes [77].

\subsubsection{Other, Positively Considered}

These theories with respect to self and other share a commonality: they consider adherence to the norm as a social benefit and othering to be detrimental to psychological health. Membership to the ingroup is seen as the goal, with outgroup membership something to be avoided or denied when suggested by ingroup members. Social power is recognized as something held by the greatest number of people representing the norm and minorities are such because they represent the few. On the other hand, there is a sense of self and other that does not view social power as residing in the greatest numerical representation. Instead, social power is considered to come with the ability of a person to make accurate predictions regarding truth [78]. In other words, those with the greatest ability to reason well and take responsibility for their decisions are, in this view, recognized as holding social power. It acts to explain why people considered in the outgroup socially often achieve great acclaim for their work as a lack of social connectedness can be seen as a cue for creative thinking [79]. In this sense, any limitations imposed by COVID-19 to make people more individual in their viewpoints-more other-is to be seen as a benefit rather than a detriment.

Self-directed learning (SDL), a term initially introduced for auto-didactic learners [80], can be seen as a process in which students take responsibility for their own learning, with or without the help of teachers and/or peers, in identifying their learning needs, formulating goals with respect to learning, and searching out the resources they require to fulfill those goals while implementing learning strategies with which they feel comfortable based on determining what will be their standard for evaluating learning outcomes [81]. In self-directed learning, the teacher and the norm, represented by the curriculum, do not define the learning objective, activities or conditions in the learning process. Regarding self-directed learning, being other has the positive benefit to the learner of mastery goal orientation in aiming to develop their competence in relation to the learning standard personally identified by the learner [82].

\section{Augmenting the Body}

The limitations introduced by COVID-19 have brought various ways in which the body has been augmented and, as such, a distance has developed between the self and what is perceived. Some of these body augmentations have been in direct contrast to what the norm previously considered important for ingroup membership [83]. Thus, the 
norms of the ingroup have changed [84]. These changes have been particularly evident in schools where learners were quickly taught the new rules and regulations brought on by COVID-19 [85]. From sociological perspectives, this migration of the norm has caused difficulties for those who gauge social power by membership to the ingroup, and this is because what represents the norm defining the ingroup is now in question. From the perspective of SDL, these limitations from COVID-19 have permitted those who are seen as other, if they accurately use reason and take responsibility for their decisions, to rise above the limitations and see them as opportunities. Three distinct ways that the self has been altered regarding the three augmentations of space-from the most public to the most personal-and how these alterations relate to ingroup attitudes in defining other are to be examined.

\subsection{Extending the Self-Videoconferencing in Public Space}

Although reported that pandemic school closures affected 94\% of the world's student population [86] according to UNESCO, the greatest percentage of students impacted by these closures was 82.8\%, occurring 30 March 2020 [87]. After declaration of the pandemic, mid-March 2020, in-class meetings were no longer permitted for learners and schooling proceeded online. The switch to online learning necessitated student access to the internet in order for learning to continue [88], yet a significant number of homes lacked internet access (one in seven in the U.S., for example [89]). Various online platforms were employed, including, but not limited to, Skype [90,91], Zoom [91-94], Google Hangouts [91,93], Cisco Webex [92], Microsoft Teams [91-95] and Google Classrooms [96]. Some of these were easier to use, others more able to be controlled by educators [96]. Zoom, a collaborative, cloudbased videoconferencing service offering online meetings, group messaging and secure session recording [97], became the most popular alternative among many options [98]. It was the preferred choice for a number of reasons: the basic program was free to all users, an account is not required, ease of operation, length of time available for sessions, screen sharing availability, and up to 50 "breakout" rooms can be created for group work [99]. However, schools were often reluctant to use Zoom because of problems with using lower bandwidths [100] and potential privacy issues [101]; however, if Zoom is set up property, it has been found entirely safe with respect to privacy [102].

While attending online lessons, learners have had a choice available to them that was also present with in-class lessons-they could attend the lesson or not. With their videos on, students could be seen by teachers to either be paying attention to the lesson or doing something else. Turning their videos off while the lesson is underway has been an option available to online learners that is not possible in-class. This has had a marked effect on teachers who have struggled with getting students to engage with the lessons when the norm had become equated with less engagement online than with in-class lessons [103]. As such, the norm developed to involve a new sense of distance from both the teacher and the material to be learned through the teacher as students with appropriate access to technology demonstrated proficiency in using online resources beyond the teacher-led video lessons [104]. Those students requiring teacher involvement for their learning - particularly special education students-were othered by the norm that had evolved to entail less teacher direction in learning [105]. If those who were othered considered themselves victims, the social power of the ingroup remained a barrier to their achievement [106]. On the other hand, if those who were othered found ways on their own to engage with mentors to take the place of teacher direction, then this change in the norm need not result in such a learner feeling victimized by the norm [107].

A technical reason why students might choose to turn off their video is a weak internet connection. This revealed an inequity among students [108]. However, from the perspective of learners, an often even greater injustice was other students and the teacher potentially witnessing how students lived. When attending in-class meetings, all students are present in the same location. During the COVID-19 school closure, students were required to be at home. This meant that others, who would never be invited to a 
student's home, had the opportunity of evaluating the conditions under which students accessed their lessons at home if the student left their video on and did not digitally alter the virtual background [109]. For those students who felt that their home atmosphere was outside the norm - either having less than would be expected or having more-students felt that they became other in showing their private space to the teacher and peers through videoconferencing [110]. This problem in relation to inequity has been a particular burden for students of color, increasing their toxic stress burden [111], an indication of a feeling of other [112]. In total, once privacy's social value is recognized, its importance with respect to individuals does not change. The reason-privacy is a fundamental right of a legitimate society [113] and despite the fact that young people are willing to disclose personal information in online environments, studies continue to report that young people value their privacy and use various strategies to shield themselves from others online [114].

Online learning can create an environment closer to the physical classroom when the video is on [115], allowing for more natural interactions [116]; yet, seeing oneself on video during a learning session was known even prior to the pandemic to make students uncomfortable looking at themselves, with most teachers and students only using video at the start of lessons and discontinuing their use after the first 2-3 weeks [117]. Once online learning became the norm with COVID-19, the previous understanding that inclass learning involved either focus on the teacher or on peers now had to be modified to include an additional focus on the self as seen with webcams. Learners have described this normative shift, requiring that they look at themselves, as giving them personal discomfort-making them feel ashamed and exposed [118] - putting them in the position of considering themselves as other. Prior studies have shown that physical self-concept accounts for most of the variation in self-esteem-academic and social self-concepts play a much lesser role [119]. Students now saw what they perceived as their shortcomings and, thus, might spend the time online either looking to see how they could improve their appearance or, if they were not satisfied with the result, turning off their videos. Most students chose to turn off their videos [120,121].

Previous to the online learning required by COVID-19, because they generally learned in spaces devoid of mirrors or continuous video camera coverage, most students were unaware of how they looked when participating during in-class lessons. With the knowledge they now gained of themselves through videoconferencing, students might experience an otherness in relation to a number of their different personal qualities: facial expressions, weight, behavior, clothing choice, hair style, posture and the general demeanor of their body. In one study, $48.5 \%$ of young people indicated that they either agreed or strongly agreed that they have become more concerned about how they look as a result of COVID-19 [122]. Some students, pre-COVID-19, may have never been aware of how they looked, let alone watched themselves on a video with others. If students now recognized differences between themselves and the ingroup defining the norms as a consequence of using the video option, these students would see themselves as other in a way that had not before the necessity of online lessons. Using video and, thus, revealing what they saw as their limitations might not only involve self-incrimination, as it might in relation to with SCT and IPT; how they looked on screen could also instigate unwanted attention by ingroup members as a violation of expected norms. Thus, students who now recognized themselves as other as a result of the use of video during online learning would turn off their video not only because of a rejection of self but also because how they appeared on video was in contrast to the normative standards set by the ingroup. To persist in the use of video would mean the student was not abiding by the ingroup standards - an important consideration in social power as recognized by SDT. Turning off the video retains a positive self-identity as specified by SIT, when the learner believes their video presence is contrary to the norm.

Students may be unprepared for how they appear on video and unhappy with the result because of COVID-19. One study [123] found that in order for face-to-face interaction to be successful during COVID-19 limitations, the following must be sufficient related to the 
lessons provided: staffing, preparation, thought, creativity and innovation. Without these, online lessons involving video were seen to jeopardize the safety, comfort and experience of young people. If they had previously felt part of the ingroup before witnessing themselves on video, their unexpected performance in front of the teacher and their peers might make them feel demoted in the ingroup, or now part of an outgroup; without empathy from the ingroup, positive intergroup attitudes and prosocial behaviors will not occur [124]. Nevertheless, if the student is willing to take responsibility for their learning by selfdirecting, rather than following the norm, then this poor showing on the video need not affect them psychologically. That the decision to self-direct has social ramifications with respect to the norm is true, although self-direction values can be secure if negatively correlated with parental restrictiveness at age 5 [125]. If the student is not guided by the norm in self-directing, being judged by the ingroup as other is irrelevant for student self-concept and student learning.

\subsection{Isolating the Self-Social Distancing in Social Space}

From a sociological standpoint, the isolation of the self from the ingroup is a major detriment as it does not permit young people to recognize the norm [126]. As the norm defines social power, this means the self becomes unaware of where power resides, how it is accessed, and what is to be expected in relation to it. With respect to defining the ingroup and various outgroups, the norm is the standard [127]. When students were forced to socially distance themselves from teachers and peers by staying home, the standards of the norm were no longer reinforced on a day-to-day basis. At home with only their families, students' understanding of who they are as a self in relation to the norm became inaccessible in comparison to pre-COVID-19, when they would be regularly informed of and judged in relation to the norm [128]; alone, they then saw themselves as other.

From the standpoint of SCT, these young people were unable to clearly recognize the "I" because there was no longer a "we" with which to compare, as the definition of the self is seen to be formed consequentially from understanding the student's role as a member of a group. Without this clear sense of self, the fear of COVID-19 was able to change and manipulate the sense of self as set out in IPT. With no ingroup available with which to compare themselves daily (SIT), students, in accordance with SDT, were unable to make use of their social power or be affected by that of others. Self-worth is diminished in accordance with IPT, as a lack of contact with the ingroup affects social resilience.

However, not all students who saw themselves as other as a result of a detachment from the norm considered this a negative experience. For those students willing and able to self-direct their learning [129], the lack of a constant reminder of the norm that resulted from social distancing made the ability to experience flow in their learning a more likely experience. Flow, the ability to become completely absorbed in a task to the extent that time disappears, is the experience that has been identified as both a regular occurrence and necessary for creative work to be productive [130,131]. When students are overwhelmed or underwhelmed, as they often are in teacher-directed learning, this leads to a lack of participation in setting learning objectives and, under these conditions, flow is not observed [132].

Isolating, as was required with COVID-19, permits the learner time and a lack of distractions to process their goal orientation and learning strategies on a deeper level than with in-class learning [133]. In recognizing themselves as other while separate from the norm, those students engaging in SDL develop analogies, and find links in their knowledge, making it easier to connect new knowledge [134]. With a lack of relationship to or interest in the norm, of those who see themselves as other who self-direct their learning, they have been found to have a greater degree of self-control in comparing their current status with their goals and updating their learning conditions as a result [135] and they invest greater effort in their personalized learning [136].

The isolation of the self that came with social distancing because of COVID-19 can be thought of as problematic from the point of view of the norm where the ingroup provides 
the necessary structure for learning. However, for the self-directed learner, this isolation is better thought of as an emphasis on self-control and autonomy with respect to learning, and this relates well with the tenets of an open, democratic society [137]. The identification of self as other in this regard, rather than being seen as a disadvantage with respect to the norm, has the potential to lead to a learner's ability to flourish and productively contribute to society through entrepreneurship [138].

\subsection{Protecting the Self-Mask-Wearing in Personal Space}

During the extent of the COVID-19 pandemic, perhaps the most important concern has been protection against contracting the disease [139]. In this regard, wearing a mask was mandated to protect all from the vocal spray that was recognized as the cause of transmission of the virus [140]. Mask-wearing was resisted, specifically by men who identified with the norms of masculinity [141], those living in rural areas [142], younger individuals, and those who did not frequent shopping centers [143]. Masks are a necessity for frontline works, and they have been recommended to be used universally, even if most are homemade and of low quality [144], yet they have been cited as "perhaps the most-powerful psychological symbol for the general public" [145].

What is a mask during COVID-19 has been called into question throughout the pandemic. It certainly goes beyond what Jung referred to as the "persona": the "social mask that one wears to adapt to the perceived expectations of others" [146]. Commercial masks were in short supply at times during the pandemic when non-standard products were used as masks. These included, but were not limited to, the following: vacuum cleaner bags, tea towels, cotton scarves, pillowcases, silk scarves and cotton T-shirts in decreasing order of protection [147]. When the N-95 mask used by frontline healthcare workers, a tightly fitting mask that seals off the wearers face and can remove $95 \%$ of particles, was credited as the "single most important part" of the armor for healthcare workers [148], those in the general public most afraid of contracting COVID-19 sought them out for personal use, creating a shortage of these masks for frontline workers, resulting in $79 \%$ of nurses being encouraged or required to reuse their masks and $36 \%$ reported reusing them for 5 days or longer [149].

Students are among those in the population who have been less likely to wear masks and, when they have, often wear them improperly, including students at the center of the initial outbreak of the pandemic in Wuhan, China, where only $32.47 \%$ of students were found to wear properly fitting masks [150]. On the street, rather than the classroom, students were even less inclined to wear a mask, with those who were better educated being more likely to wear one [151]. Chinese students, stigmatized for the pandemic arising in China, were those most likely to wear masks - both as a result of belief in their effectiveness and to assist in physical support of their being considered other [152]. However, this strategy by Chinese students was often found counterproductive as conservative individuals have been more comfortable with Asians if they were not wearing a mask, most specifically if these Asians were male [153].

Asians have been identified as those students who have been, as a result of the importance of mask-wearing to counter COVID-19 infection, othered with respect to the norm-both regarding their preferred use of wearing a mask for their own protection in contrast to most students and the lack of trust other students may have of them because they wear a mask [154]. However, the reason for this othering goes beyond political sentiments of those representing the norm. Facial emotion recognition is seen as crucial for social interaction and the wearing of masks challenges such recognition; this is especially so in depicting anger, sadness and disgust-altering the perception of threat by the norm [155].

One of the ways in which self has become other for students in general is concerning their now self-perceived breath odor [156]. Individuals who, previous to COVID-19, had no knowledge of their bad breath now became self-conscious of halitosis. Self-perception of breath odor is multifactorial and relates to body image in both physiological and psychological ways [157]. Discovering that one has breath odor that differs from the norm and 
is considered offensive has been found to have significant negative effects on quality of life, producing a feeling of otherness bringing on mood disordered, depression, anxiety and behavioral changes [158].

Additional ways in which students have been othered as a result of wearing masks is the significant increase in acne flare-up [159] and the contribution of mask-wearing to dry eye diseases' symptoms [160], particularly a problem for those students wearing contact lenses [161]. Furthermore, students may notice a change in the self-perception of their voice [162] that they find othering as it may affect speech intelligibility in the classroom, specifically for males [163]. This becomes a significant problem for students when they cannot understand their teachers through their masks, decreasing their school performance and, thus, their understanding of the norm [164]. Students with hearing loss were at an even greater disadvantage [165]. Students may also have concerns that their ability to participate in sports, as a result of wearing masks, must be curtailed, although cloth masks have been found to have no effect on vigorous exercise performance in healthy individuals [166]. For those students involved with vocal music, the effect of othering has been intense, having a major impact on their sense of self [167].

\subsection{The Body in Space}

Each of the augmentations presented are those with which all students had to contend during COVID-19 as learners. They were examined with the thought that the enhancements that were furthest away in space with respect to intimate space would be those more easily incorporated into a new understanding of self in relation to readjusted norms defined by the ingroup. In other words, for example — at the one extreme - students learning to turn off the video of the computer when interacting online because of not wanting teachers and peers to see how they live is less affronting to the self than, at the other end, coming to know that one has bad breath as a result of wearing a mask. The first, though creating barriers to participation, generating unnecessary stress, and contributing to an environment of distrust that is seen to undermine learning [168], only necessarily affects the student in the cyberspace if they choose to turn on the video. The second means that the student will be constantly wondering if they can get in close proximity to people because of their halitosis, even after the limitations of COVID-19 have been removed in the future. Regarding their video presence, students may decide to act on changing how they look given their problem with seeing themselves on screen. On the other hand, once their breath is perceived as noxious as a result of mask-use, the learner will continue to be embarrassed, anxious and have a reduction in their level of self-esteem as their odorous breath remains [169].

\section{Discussion}

The understanding of self is grounded in the body. Augmentations to the body permit an accentuated access of the body to sensations. However, the effect of these amplified sensations is, at the same time, less intense the further these enhancements are from the original body. An effect of the COVID-19 pandemic has been the demand for body augmentation in a number of ways in each of three additional areas of space beyond the intimate. Through the least intimately affecting to the most, this has been examined specifically through extending, isolating and protecting of the self.

It was argued that students were those members of society most affected by COVID-19 limitations because of ongoing subordinate connections with parents, teachers and older or more accomplished peers and, as such, are society's members with the greatest likelihood of what represents the self then evolving to other based on these augmentations. An example of each was investigated from the perspective of various sociological theories to suggest in what ways self could been seen as other as a result of COVID-19. With respect to extending the self, videoconferencing was considered as the body augmentation that was experienced by students worldwide as a result of school lockdowns, which also brought the social distancing of students-the second enhancement of the self that was studied regarding students-representing a form of isolation. Lastly, the final body augmentation inspected 
was the protecting of the self through the wearing of masks, a necessary requirement of students. In each case, these examples were considered from the perspective of in what ways the understanding of self might be transformed to other in the case of students.

In their concern with the norm as the foundation for the ingroup, four sociological theories were used to evaluative the possible change from self to other-Self-Categorization theory (SCT), Social Identity Theory (SIT), Identity Process Theory (IPT) and Social Dominance Theory (SDT). Each in various ways upholds a movement from self to other as detrimental. The aim, in the estimation of these theories, is adherence to the norm through identification with the ingroup. To become other was to be relegated to an outgroup and, as such, lose social power. As social power in relation to the ingroup is considered necessary for mental and physical health [170] from the sociological lens, the aim with respect to the limitations imposed by COVID-19 regarding these sociological theories is for students to regain social support [171]. This is achieved by reidentifying with the ingroup and, again, basing their decisions and actions in relation to the norm [172].

\section{Self-Directed Learning}

Psychologically, the transition from self to other that may have occurred in students as a result of COVID-19 requirements is recognized in a different way. The self in this estimation is what is true to the learner, while other develops when the self identifies with ways of thinking and acting that are out of character for the particular learner in that learner's view. Here, character implies what is stamped on individuals as well as abiding by the moral and ethical principle learned in relation to the norm [173]. Yet, the evaluation of this move to being out of character is not necessarily considered something requiring return to what is true to the self. It might be that it is time for the self to evolve and to change in a way that is out of character. In this way, becoming other may be something disquieting, but not a change to try to avoid.

One psychological theory in particular regards the learning process as internally regulated $[174,175]$, recognized in adult education as SDL; it equates the othering that comes from not identifying with the norm of the ingroup as something positive to be acted on. Furthermore, when SDL-based on what the learner personally values-considers other learners as also self-directing their learning in communities based on consensus decision making by finding a time and place to do what each learner values, the selfdirection that comes from being other evolves from an individual approach to learning to a way of organizing social interactions outside of the norm of ingroups [176].

A major effect of COVID-19 on learners is that they have, by necessity, become self-directed learners [177]. This relates (among other things) to their having to work online through videoconferencing, their isolation during lockdowns, and their difficulties understanding social cues from interacting with teachers and peers wearing masks when in the classroom. SDL skills are seen as the most important for students since the advent of COVID-19 [178]. Yet, for the majority of the students now self-directing their learning, this is not a preferred choice because it requires time-management skills, the acceptance of personal responsibility and a way of learning that is very different from teacher-directed instruction [179]. Educated to look to the norm of the ingroup for guidance and evaluation of their behavior, these students feel lost and overwhelmed with self-directed learning [180], and more comfortable with teacher-directed lessons in a classroom of peers.

With COVID-19, self-directed learning became essential, but it was a learning strategy that was not welcomed by those students focused on the norm through understanding the ingroup. On the other hand, these students' need for teacher-directed learning was a skill that they learned initially upon first entering the education system. As such, skills for SDL can also be learned. A six-step model to develop SDL among students was recently identified as useful in developing the skills for self-directed learning [181]:

- Develop goals for study;

- Outline how it will be known those goals have been achieved;

- Identify the structure and sequence of learning activities; 
- Create a timeline for activities' completion;

- Identify resources needed to achieve each goal;

- Locate a mentor/teacher to provide feedback on the plan.

Although following these steps is not a necessity for success in SDL, a student who felt lost and overwhelmed with SDL would find this type of organization of their SDL helpful because it relates directly to those qualities that have been recognized as lacking in students who would prefer teacher-directed learning, as this six-step model focuses on time-management, accepting personal responsibility and highlights the differences between teacher-direction in learning and self-direction.

A scale for assessing SDL [182], identifying the characteristics of self-directed learners, considers that such learners exhibit: initiative, independence, persistence in learning, an acceptance of responsibility for their own learning, a view of problems as challenges rather than obstacles, curiosity, self-discipline, self-confidence, a strong desire to learn, time-management skills, goal orientation, an ability to pace their learning in relation to a plan for completing work, and pleasure from learning. This Self-Directed Learning Readiness Scale (SDLRS) has been tested for validity $[183,184]$. However, given that there is no required and absolute method for successful SDL, it is not surprising that that the SDLRS has been criticized because SDL is not a stable, context-independent construct that can be measured through the use of standardized questionnaires [185]; as well, whether or not learners think they have the qualities for SDL has been found to not equate with whether they do possess these qualities in practice [186]. Learners who do demonstrate these qualities are self-directed; however, not all self-directed learners demonstrate each of these qualities. More recent research [187] has indicated, of those subsequent measures that have been developed modifying the original SDLRS, a four-factor 36-item scale has the greatest likelihood of predicting SDL [188]. The factors are as follows:

- Critical self-evaluation

- I evaluate my own performance;

- I like to evaluate what I do.

- Learning self-efficacy

- I enjoy learning new information;

- I want to learn new information.

- Self-determination

- I prefer to set my own goals;

- I prefer to set my own learning goals.

- Effective organization for learning

- I do not manage my time well (reversed);

$\circ \quad$ I am self-disciplined.

Regardless of the actual qualities of self-directed learners, they are those whose understanding of their self is other than the norm defined by the ingroup. Given that selfdirected learners consider themselves other with respect to the ingroup, their evaluation by teachers has been found to need primary concentration on reducing learners' anxiety with respect to the self-directed approach they take to learning, while acknowledging how cultural influences affect teacher evaluation [189], as defined by the norms of the ingroup.

\section{Conclusions}

Why the COVID-19 migration of self into other is problematic to the psyche has been discussed from a number of perspectives. To be considered is the possible long-term consequences for an ongoing lack of learner recognition by the norm's ingroup. Following this assessment, parents and teachers as caregivers will be provided with information on how they might become better able to provide mentorship to students regarding what they can expect in now seeing self as other through their encounter with COVID-19, with the aim of diminishing possible long-term psychological, social and physical consequences. 


\subsection{Change to Interpersonal Distances with COVID-19}

Pre-COVID-19, the three types of distance experienced by learners (a fourth, intimate distance, is only available to close relationships) were (a) public distance, more than $210 \mathrm{~cm}\left(6^{\prime}\right)$ from the learner, where the voice shifts to higher volumes and eye contact is minimized; (b) social distance, $122-120 \mathrm{~cm}\left(4^{\prime}-6^{\prime}\right)$, for formal interactions; and (c) personal distance, $46-122 \mathrm{~cm}\left(18^{\prime \prime}-4^{\prime}\right)$ maintained for interactions with friends in which vision and voice are clear [190]. With respect to extending public space through online communication, the norms have changed significantly. Because the video camera captures an area of the home, strangers might have the ability to scrutinize it. As a result, with videoconferencing, the spatial meaning of home as a divider of public distance became unclear. Unless the learner had the knowledge and wherewithal to create a virtual background for their videoconferencing sessions, public distance was eliminated when the video was on during online communication. Having to keep apart from others at least six feet when attendance was permitted in the school building, and during lockdown social distancing by each household, meant that social distance was extended to what previously was public distance, something that seemed odd and impolite. The wearing of masks, by putting a barrier between the self and other, effectively eliminated personal distance as neither the vision of others wearing masks nor their voice remained clear [191].

With COVID-19, the norms have changed for interpersonal distances. Unless video is kept turned off, there is no longer a meaning to public space. Anyone participating in an online video conference where the video is left on and background unaltered is invited into what, for learners, would previously have been a space only accessible by friends and family. The change to social space has made communication among students and with teachers more difficult and demanded that students and teachers each raise their voices to be heard, not only because of the increased distance among them but also because of the masks they are wearing. Furthermore, because of the masks on the one hand and the need to social distance on the other, the realm of personal space is no longer meaningful.

\subsection{Sociological Considerations}

Seen with a sociological lens, schooling is society's method of inculcating the norms of the ingroup into learners [192]. When those norms change, the social influence of those with social power determines the change in the ingroup and schooling devises tests of conformity to the new norms [193]. What is important is not only the norms themselves that are taught to be believed and valued but also how they are taught and why [194]. With the limitations of COVID-19, what has changed related to the norms is the understanding of the limits of the three interpersonal distances beyond intimate space. With these changes to the meaning of the levels of interpersonal space, the norms as defined by the ingroup have been altered.

As a result of COVID-19, the ingroup with respect to the norms to be taught through schooling have become as follows. Regarding public space, there is a general acceptance that keeping the video turned off during online communication is acceptable in promoting equality and trust among learners and teachers [195]. Those who keep their videos turned on and backgrounds unadulterated, by definition, are students who feel they have nothing to hide or who do not set public boundaries. It is they who become other when the norms of society have recognized keeping the view of the home private is what is supported by the ingroup. With respect to social space, as the distance between individuals has expanded, the norm has become raising one's voice to talk with others and repeating oneself to be understood. As such, the norm has become that communication in a learning setting requires more personal energy than in the past. Those students who continue to talk at the level they did pre-COVID-19 or who neglect to repeat what they have said when this is required for comprehension become those who are othered [196]. Finally, when required to wear a mask, the ingroup are those who avoid personal space in learning situations, instead keeping interactions at the social space level [197]. 
Recognizing these changes to the interpersonal levels of space as a result of COVID-19 means that, in keeping with the norms of the ingroup, parents and teachers as caregivers would do well to making these changes to interpersonal space known to learners. Students need to know that unless they conform to these new understandings, they will be othered by society.

These changes to the norm that learners are asked to accept and conform to are in contrast to previous understanding of what was appropriate behavior. As such, this can be recognized as causing trauma to vulnerable learners who were part of the ingroup of the previous understanding of interpersonal space. It can also exacerbate the disconnect felt by students who are increasingly othered as a result of the pandemic-Asian students, most notably [198]. Effects on these learners can be to their nervous systems, endocrine systems and hypothalamic-pituitary-adrenal axes. As well, trying to adhere to these changes and not be othered can result in psychological crises from feelings of abandonment, despair, incapacity and exhaustion [199].

From the sociological point of view, encouraging people to think collectively rather than personally is critical to controlling the pandemic [200] and to introducing the new norms to the ingroup. In this way, mentoring, which can be provided to students by their parents and teachers directly, and their peers in everyday interaction, can promote these newly valued ways of socially interacting. In essence, the most effective mentors in convincing students to conform to the current norms promoted by COVID-19 considerations are those parents, teachers and peers who are the most educated about the changes and those in the least conflict with the learners [201]. It is in this way that these students are least likely to feel othered in relation to the pandemic.

\subsection{Self-Directed Learning Standpoint}

Although interpersonal space is important to those who naturally prefer SDL when concerned with social interaction regarding their learning, the changes that have been brought by COVID-19 are of less importance. The reason is that SDL is engaged with learning in relation to what the student personally values, not what is adhered to by the ingroup representing the norm. Self-directed learners recognize that they are other and part of an outgroup in not being guided by the norm. Consequently, any additional identification of them as other as a result of COVID-19 will have less effect than it might on those who are normatively influenced.

Social distancing for the self-directed learner is not a detriment for SDL as this type of learning is best undertaken where and when the learner is able to self-isolate to concentrate on learning. In effect, the limitations imposed by COVID-19 may, by taking away the necessity of social interaction in a learning setting, reduce the stress of those involved with SDL. Parents and teachers can act as mentors to self-directed learners by promoting mindfulness [202]. Doing so can help students reduce stressors that detract from SDL. They can do so in at least three ways: by cultivating self-directed attention rather than reacting to the rapidly changing situation of COVID-19, encouraging them to regulate negative thoughts and feelings that take away from their learning, and by advising them to view adverse events non-judgmentally as opportunities for further learning. In providing this type of mentoring, SDL can be both stress-reducing and intellectually productive during COVID-19, although the students who engage in it may be further othered by the ingroup of the norm.

\subsection{Recommendations Regarding Mentoring}

COVID-19 has brought with it a reinterpretation of self as other in learners. With respect to augmentations to their bodies, this reinterpretation by learners as learners has taken on at least these three specific forms: (1) by extending their body through witnessing themselves regularly in videoconferencing learning sessions, (2) by isolating their body as a result of spending time apart from peers in social distancing at home, and (3) by protecting their body through required mask-wearing where learners now consider 
who they represent in a mask. The mentoring that might be provided by teachers and parents to learners with respect to reducing negative feelings in them resulting from these forms of body augmentation can be provided from two different standpoints-normative and self-directed.

For those learners guided by the norm, and the thought of considering themselves other is distressing, teachers and parents can help these learners decrease their discomfort by mentoring them in the new norms for behavior as they change in relation to COVID-19. This is best achieved by teachers and parents abiding by those rules themselves in acting as role models, both in person and virtually [203], especially with respect to minorities-those learners more likely to seek mentoring during COVID-19 [204].

Regarding the loss of private space from video conferencing, those learners who might feel self has crossed the line to other by having their surroundings revealed to teachers and classmates through online learning can be mentored to find ways to digitally enhance their backgrounds. However, if it is seeing themselves on camera that is causing their assessment of themselves as other, mentorship can support turning off their camera during video conferencing sessions-this is especially so if they have a weak internet connection. As well, it can also include encouraging learners to be proactive in finding ways to increase the strength of their internet connection at home.

One of the ways learners concerned with norms can feel themselves othered is by the requirement for social distancing. Therefore, in advising those learners who feel othered by the use of video in conferencing not to use their video, they should be mentored to find a preferred form of online learning. This is especially so since online learning has been found to improve student exam performance during COVID-19 [205]. In coming to understand the nuances of norms, daily interaction with teachers and peers during school hours is imperative. For this reason, learners should be advised to attend any conferencing related to school in a manner that makes them less distressed. This includes mentoring learners to use other forms of social media for continuing peer contact, such as using Discord, with such mentoring often best provided by peers themselves [206].

Finally, with respect to the impact of masks in making those learners concerned with norms feel troubled by considering themselves other, learners might be mentored by teachers and parents to speak clearly when wearing masks [207] and use additional body language to convey their meaning [208] when appropriate. As well, they could be encouraged to ask others to speak clearly [164]. With respect to the worrying feeling of other that comes from bad breath or from increased skin problems, mentoring learners with respect to effective hygiene-and having teachers and parents take these concerns seriously when they arise, offering timely solutions-has been found effective [209] in reducing the distress that can arise from these conditions in making the learner feel as other.

Those learners who are self-directed will assess the result of considering themselves other from another perspective, seeing this disassociation from what they knew of themselves pre-COVID-19 as an opportunity for personal growth [178]. In not being afraid of seeing themselves as other, self-directed learners are best mentored in a way that encourages their self-direction rather than focuses on assuming the recognition of oneself as other to be a problem. To this extent, the six-step model to develop SDL among students that was recently identified as useful in developing the skills for self-directed learning [181] is something that teachers and parents can consider when mentoring self-directed learners. To determine if the learner is self-directed and, thus, could benefit from this form of mentoring, the modified SDLRS, four-factor 36-item scale has been found [188] to produce the greatest likelihood of predicting SDL. The outcome to be expected for self-directed learners in their learning is the experience of flow, leading to creativity in what they accomplish [130,131]. Mentoring these learners to value flow in their work is a way to make the experience of considering themselves other continue as a positive outcome during COVID-19.

In not being perturbed by the migration from self to other that has resulted from COVID-19 limitations, self-directed learners are those who have the psychological constitution to consider the dividing line between self and other from an objective perspective. As 
such, they can question what defines the body and the space around it in differentiating self from other. Furthermore, they can be critical of the assumptions regarding in what way the separation between self and other is psychologically and sociologically necessary. Mentoring self-directed learners to examine the presuppositions of each of the theories of self and other that have been presented in this report is a starting point. One way a critique of norms regarding self/other can be offered by these learners is investigating how empathy can blur this assumed distinction [31]. Larger social justice issues can be considered, as SDL is a form of learning that permits mentoring in self-developing [210] with respect to the more fundamental aspects of questioning knowledge boundaries.

\subsection{Limitations}

This report was constructed based on understanding the self-other distinction depends fundamentally on the relationship of the body in the world. The assessment was undertaken from the position that the most important aspect of the body in the world relates to exterior, interpersonal space. However, medical conditions that can result from identifying the self as other were only touched on and play an important role in the mental and physical health of students, posing a limitation of this study.

Furthermore, the analysis of self and other was with respect to four sociological theories (Self-Categorization Theory, Social Identity Theory, Identity Process Theory, and Social Dominance Theory). There are other sociological theories that might have been used, but were not. The Theory of "Societalization" [211] and Social Disorganization Theory [212] are two other sociological theories that might have been investigated with respect to COVID-19 and the distinction between self and other. Neither of these were selected as both of their interests are somewhat outside the concerns of learners. The Theory of "Societalization" examines how socially disruptive extreme events affect the role of what is valued in society through business, while Social Disorganization Theory proposes that neighborhood characteristics, such as poverty, residential mobility, population density and overcrowding, lead to the increased levels of disadvantage and disorder associated with high rates of childhood trauma. Both of these theories, although they would have provided additional insight into the self-other distinction, were considered marginal in their appreciation of learners and were, therefore, excluded from consideration.

Regarding psychological theories, there was only one that was referenced and it was identified from the perspective of work in adult education-self-directed learning. There are other psychological theories to understanding COVID-19 that might have been mentioned, including Terror Management Theory [213] and Attachment Theory [214]. As the concentration of both of these theories is to provide support for therapy rather than to be descriptive of the self-other distinction with regard to learning, they were not selected for inclusion. Furthermore, the difference that was drawn between the sociological theories and the selected psychological theory with respect to self-other was that, for sociology, adherence or non-adherence with normative practices related to the ingroup was foremost; with SDL, personal values mattered in defining the self, and the othering of the norm was of less consequence with respect to learning.

An additional consideration is whether SDL, developed initially for adult learners, is relevant to children's learning. Extensive, longitudinal research has been conducted to confirm both the appropriateness of SDL for young people (referred to as unschoolers) and its ability to support mental health and career aspirations $[215,216]$.

Lastly, advice was offered to parents and teachers as caregivers regarding how they might act as mentors, both with respect to those students focused on the ingroup defining the norm and for those who are self-directed learners reflecting personal values in their learning. The research that has been carried out in the area of mentoring during COVID-19 from either perspective is limited and, thus, the suggestions proposed remain conditional, requiring further validation. 
Funding: This research received no external funding.

Institutional Review Board Statement: Not applicable.

Informed Consent Statement: Not applicable.

Data Availability Statement: Not applicable.

Conflicts of Interest: The author declares no conflict of interest.

\section{References}

1. Liu, Y.-C.; Kuo, R.-L.; Shih, S.-R. COVID-19: The first documented coronavirus pandemic in history. Biomed. J. 2020, 43, 328-333. [CrossRef]

2. World Health Organization. Novel Coronavirus Disease Named COVID-19; World Health Organization; United Nations Economic and Social Council: Geneva, Switzerland, 2020; Available online: https:/ /www.who.int/emergencies/diseases/novelcoronavirus-2019/events-as-they-happen (accessed on 20 August 2021).

3. Cucinotta, D.; Vanelli, M. WHO Declares COVID-19 a Pandemic. Acta Biomed. 2020, 91, 157-160. [CrossRef]

4. Chu, D.K.; Hui, K.P.; Gu, H.; Ko, R.L.; Krishnan, P.; Ng, D.Y.; Liu, G.Y.; Wan, C.K.; Cheung, M.C.; Ng, K.C.; et al. Introduction of ORF3a-Q57H SARS-CoV-2 Variant Causing Fourth Epidemic Wave of COVID-19, Hong Kong, China. Emerg. Infect. Dis. 2021, 27, 1492-1495. [CrossRef] [PubMed]

5. Weintraub, K. The Fourth Wave of COVID-19 Cases Is Here. Will We Escape the UK's Fate? It's Too Soon to Know. 2021. Available online: https:/ / www.usatoday.com/story/news/health/2021/07/16/covid-19-fourth-wave-pandemic-surge-deathshospitalizations/7976034002/ (accessed on 20 August 2021).

6. Jee, Y. WHO International Health Regulations Emergency Committee for the COVID-19 outbreak. Epidemiol. Health 2020, 42, e2020013. [CrossRef] [PubMed]

7. Dionne, K.; Turkmen, F. The Politics of Pandemic Othering: Putting COVID-19 in Global and Historical Context. Int. Organ. 2020, 74, E213-E230. [CrossRef]

8. Li, Y.; Nicholson, H.L. When "model minorities" become "yellow peril"-Othering and the racialization of Asian Americans in the COVID-19 pandemic. Sociol. Compass 2021, 15, e12849. [CrossRef] [PubMed]

9. Hahm, H.C.; Xavier Hall, C.D.; Garcia, K.T.; Cavallino, A.; Ha, Y.; Cozier, Y.C.; Liu, C. Experiences of COVID-19-related anti-Asian discrimination and affective reactions in a multiple race sample of U.S. young adults. BMC Public Health 2021, 21, 1563. [CrossRef]

10. Johnson, J.L.; Bottorff, J.L.; Browne, A.J.; Grewal, S.; Hilton, B.A.; Clarke, H. Othering and being othered in the context of health care services. Health Commun. 2004, 16, 255-271. [CrossRef] [PubMed]

11. Weis, L. Identity Formation and the Processes of "Othering": Unraveling Sexual Threads. J. Educ. Found. $1995,9,17$.

12. Chimakonam, J.O. Othering, Re-othering, and De-othering: Interrogating the Skolombo's Fight-Back Strategy. In Handbook of African Philosophy of Difference; Springer International Publishing: Cham, Switzerland, 2020; pp. 433-448. [CrossRef]

13. Tesi, A.; Aiello, A.; Morselli, D.; Giannetti, E.; Pierro, A.; Pratto, F. Which people are willing to maintain their subordinated position? Social dominance orientation as antecedent to compliance to harsh power tactics in a higher education setting. Personal. Individ. Differ. 2019, 151, 109390. [CrossRef]

14. Neff, K. Self-Compassion: An Alternative Conceptualization of a Healthy Attitude Toward Oneself. Self Identity 2003, 2, 85-101. [CrossRef]

15. De Rosa, A.S.; Mannarini, T. Covid-19 as an "invisible other" and socio-spatial distancing within a one-metre individual bubble. Urban Des. Int. 2021, 26, 370-390. [CrossRef]

16. Bland, A.M. Existential Givens in the COVID-19 Crisis. J. Humanist. Psychol. 2020, 60, 710-724. [CrossRef]

17. Madzia, R. Mead and self-embodiment: Imitation, simulation, and the problem of taking the attitude of the other. Osterr. Z. Soziologie 2013, 38, 195-213. [CrossRef]

18. Hall, E. The Hidden Dimension; Doubleday: New York, NY, USA, 1966.

19. Sharma, K. Seeing Body Through Sociological Lens. Res. J. Soc. Sci. 2019, 12, 13-17. [CrossRef]

20. Knoblich, G.; Flach, R. Action identity: Evidence from self-recognition, prediction, and coordination. Conscious. Cogn. 2003, 12, 620-632. [CrossRef]

21. Gallese, V.; Sinigaglia, C. The bodily self as power for action. Neuropsychologia 2010, 48, 746-755. [CrossRef]

22. Leder, D. The Absent Body; University of Chicago Press: Chicago, IL, USA, 1990.

23. Featherstone, M. Body Modification: An Introduction. Body Soc. 1999, 5, 1-13. [CrossRef]

24. De Alwis, R.; Chen, S.; Gan, E.S.; Ooi, E.E. Impact of immune enhancement on Covid-19 polyclonal hyperimmune globulin therapy and vaccine development. EBioMedicine 2020, 55, 102768. [CrossRef]

25. Kostoff, R.N.; Kanduc, D.; Porter, A.L.; Shoenfeld, Y.; Calina, D.; Briggs, M.B.; Spandidos, D.A.; Tsatsakis, A. Vaccine- and natural infection-induced mechanisms that could modulate vaccine safety. Toxicol. Rep. 2020, 7, 1448-1458. [CrossRef] [PubMed]

26. Cirrincione, L.; Plescia, F.; Ledda, C.; Rapisarda, V.; Martorana, D.; Moldovan, R.E.; Theodoridou, K.; Cannizzaro, E. COVID-19 Pandemic: Prevention and Protection Measures to Be Adopted at the Workplace. Sustainability 2020, 12, 3603. [CrossRef]

27. Vazquez-Munoz, R.; Lopez-Ribot, J.L. Nanotechnology as an Alternative to Reduce the Spread of COVID-19. Challenges 2020, 11, 15. [CrossRef] 
28. Kim, J.; Kim, J.; Wang, Y. Uncertainty risks and strategic reaction of restaurant firms amid COVID-19: Evidence from China. Int. J. Hosp. Manag. 2021, 92, 102752. [CrossRef]

29. Pikoos, T.D.; Buzwell, S.; Sharp, G.; Rossell, S.L. The COVID-19 pandemic: Psychological and behavioral responses to the shutdown of the beauty industry. Int. J. Eat. Disord. 2020, 53, 1993-2002. [CrossRef]

30. Horne, C. The Enforcement of Norms: Group Cohesion and Meta-Norms. Soc. Psychol. Q. 2001, 64, 253-266. [CrossRef]

31. Decety, J.; Lamm, C. Human empathy through the lens of social neuroscience. Sci. World J. 2006, 6, 1146-1163. [CrossRef] [PubMed]

32. Swami, V.; Horne, G.; Furnham, A. COVID-19-related stress and anxiety are associated with negative body image in adults from the United Kingdom. Personal. Individ. Differ. 2021, 170, 110426. [CrossRef]

33. Minkos, M.L.; Gelbar, N.W. Considerations for educators in supporting student learning in the midst of COVID-19. Psychol. Sch. 2021, 58, 416-426. [CrossRef] [PubMed]

34. Kira, I.A.; Shuwiekh, H.A.; Rice, K.G.; Ashby, J.S.; Elwakeel, S.A.; Sous, M.S.; Alhuwailah, A.; Baali, S.B.; Azdaou, C.; Oliemat, E.M.; et al. Measuring COVID-19 as Traumatic Stress: Initial Psychometrics and Validation. J. Loss Trauma 2021, 26, 220-237. [CrossRef]

35. Roberto, K.J.; Johnson, A.F.; Rauhaus, B.M. Stigmatization and prejudice during the COVID-19 pandemic. Adm. Theory Prax. 2020, 42, 364-378. [CrossRef]

36. Webster, D.; Rivers, N. Resisting resilience: Disrupting discourses of self-efficacy. Pedagog. Cult. Soc. 2019, 27, 523-535. [CrossRef]

37. Xiao, S.; Luo, D.; Xiao, Y. Survivors of COVID-19 are at high risk of posttraumatic stress disorder. Glob. Health Res. Policy 2020, 5, 29. [CrossRef]

38. Tai, D.B.G.; Shah, A.; Doubeni, C.A.; Sia, I.G.; Wieland, M.L. The Disproportionate Impact of COVID-19 on Racial and Ethnic Minorities in the United States. Clin. Infect. Dis. 2021, 72, 703-706. [CrossRef]

39. Kantamneni, N. The impact of the COVID-19 pandemic on marginalized populations in the United States: A research agenda. J. Vocat. Behav. 2020, 119, 103439. [CrossRef]

40. Hayden, M.R. An Immediate and Long-Term Complication of COVID-19 May Be Type 2 Diabetes Mellitus: The Central Role of $\beta$-Cell Dysfunction, Apoptosis and Exploration of Possible Mechanisms. Cells 2020, 9, 2475. [CrossRef] [PubMed]

41. Wang, G.; Zhang, Y.; Zhao, J.; Zhang, J.; Jiang, F. Mitigate the effects of home confinement on children during the COVID-19 outbreak. Lancet 2020, 395, 945-947. [CrossRef]

42. Dodson, N.A.; Langer, M. The Reproductive Health Care of Transgender Young People: A Guide for Primary Care Providers. Pediatr. Ann. 2019, 48, e64-e70. [CrossRef] [PubMed]

43. Meltzoff, A.N. Foundations for developing a concept of self: The role of imitation in relating self to other and the value of social mirroring, social modeling, and self practice in infancy. In The Self in Transition: Infancy to Childhood; Cicchetti, D., Beeghly, M., Eds.; University of Chicago Press: Chicago, IL, USA, 1990; pp. 139-164.

44. Campbell, A.; Kane, I. Mentoring and Primary School Culture. In Mentors in Schools; McIntyre, D., Hagger, H., Eds.; Routledge: London, UK, 1996; pp. 9-33. [CrossRef]

45. Buheji, M.; Hassani, A.; Ebrahim, A.; da Costa Cunha, K.; Jahrami, H.; Baloshi, M.; Hubail, S. Children and Coping During COVID-19: A Scoping Review of Bio-Psycho-Social Factors. Int. J. Appl. Psychol. 2020, 10, 8-15. [CrossRef]

46. Fuchs, S. Observing Facts and Values: A Brief Theory and History: Observing Facts and Values. Can. Rev. Soc. 2017, 54, 456-467. [CrossRef] [PubMed]

47. Van der Bles, A.M.; Van Der Linden, S.; Freeman, A.L.; Mitchell, J.; Galvao, A.B.; Zaval, L.; Spiegelhalter, D.J. Communicating uncertainty about facts, numbers and science. R. Soc. Open Sci. 2019, 6, 181870. [CrossRef] [PubMed]

48. Martin, A.K.; Huang, J.; Hunold, A.; Meinzer, M. Dissociable Roles Within the Social Brain for Self-Other Processing: A HD-tDCS Study. Cereb. Cortex 2019, 29, 3642-3654. [CrossRef] [PubMed]

49. Symons, C.S.; Johnson, B.T. The self-reference effect in memory: A meta-analysis. Psychol. Bull. 1997, 121, 371-394. [CrossRef]

50. Lockwood, P.L.; Wittmann, M.K.; Apps, M.A.; Klein-Flügge, M.C.; Crockett, M.J.; Humphreys, G.W.; Rushworth, M.F. Neural mechanisms for learning self and other ownership. Nat. Commun. 2018, 9, 4747. [CrossRef] [PubMed]

51. Crowell, S. On what matters. Personal identity as a phenomenological problem. Phenomenol. Cogn. Sci. 2021, 20, 261-279. [CrossRef]

52. Quesque, F.; Brass, M. The Role of the Temporoparietal Junction in Self-Other Distinction. Brain Topogr. 2019, 32, 943-955. [CrossRef] [PubMed]

53. Van Overwalle, F.; Manto, M.; Cattaneo, Z.; Clausi, S.; Ferrari, C.; Gabrieli, J.D.; Guell, X.; Heleven, E.; Lupo, M.; Ma, Q.; et al. Consensus Paper: Cerebellum and Social Cognition. Cerebellum 2020, 19, 833-868. [CrossRef] [PubMed]

54. Turner, J.C.; Hogg, M.A.; Oakes, P.J.; Reicher, S.D.; Wetherell, M.S. Rediscovering the Social Group: A Self-Categorization Theory; Basil Blackwell: New York, NY, USA, 1987.

55. Turner, J.C.; Oakes, P.J.; Haslam, S.A.; McGarty, C. Self and Collective: Cognition and Social Context. Personal. Soc. Psychol. Bull. 1994, 20, 454-463. [CrossRef]

56. Hogg, M.A.; Turner, J.C. Intergroup behavior, self-stereotyping and the salience of social categories. Brit. J. Soc. Psychol. 1987, 26, 325-340. [CrossRef]

57. Van Overwalle, F.; Baetens, K.; Mariën, P.; Vandekerckhove, M. Social cognition and the cerebellum: A meta-analysis of over 350 fMRI studies. Neuroimage 2014, 86, 554-572. [CrossRef] [PubMed] 
58. Tajfel, H. Social psychology of intergroup relations. Ann. Rev. Psychol. 1982, 33, 1-30. [CrossRef]

59. Aberson, C.L.; Healy, M.; Romero, V. Ingroup Bias and Self-Esteem: A Meta-Analysis. Personal. Soc. Psychol. Rev. 2000, 4, 157-173. [CrossRef]

60. Hogg, M.A.; Abrams, D. Social motivation, self-esteem, and Social Identity. In Social Identity Theory: Constructive and Critical Advances; Abrams, D., Hogg, M.A., Eds.; Springer: New York, NY, USA, 1990; pp. 28-47.

61. Breakwell, G.M. Identity Process Theory. In The Cambridge Handbook of Social Representations; Sammut, G.E., Andreouli, E.E., Gaskell, G.E., Valsiner, J.E., Eds.; Cambridge University Press: Cambridge, UK, 2015; pp. 250-266.

62. Breakwell, G.M.; Fino, E.; Jaspal, R. The Identity Resilience Index: Development and Validation in Two UK Samples. Identity 2021, 1-17. [CrossRef]

63. Breakwell, G.M.; Jaspal, R. Identity change, uncertainty and mistrust in relation to fear and risk of COVID-19. J. Risk Res. 2021, 24, 335-351. [CrossRef]

64. Breakwell, G.M. Mistrust, uncertainty and health risks. Contemp. Soc. Sci. 2020, 15, 504-516. [CrossRef]

65. Taquet, M.; Luciano, S.; Geddes, J.R.; Harrison, P.J. Bidirectional Associations between COVID-19 and Psychiatric Disorder: Retrospective Cohort Studies of 62354 COVID-19 Cases in the USA. Lancet Psychol. 2020, 8, 130-140. [CrossRef]

66. Sidanius, J.; Pratto, F. Social Dominance: An Intergroup Theory of Social Hierarchy and Oppression; Cambridge University Press: Cambridge, UK, 1999.

67. Pratto, F.; Sidanius, J.; Levin, S. Social dominance theory and the dynamics of intergroup relations: Taking stock and looking forward. Eur. Rev. Soc. Psychol. 2006, 17, 271-320. [CrossRef]

68. Kteily, N.S.; Sidanius, J.; Levin, S. Social dominance orientation: Cause or 'mere effect'? Evidence for SDO as a causal predictor of prejudice and discrimination against ethnic and racial outgroups. J. Exp. Soc. Psychol. 2011, 47, 208-214. [CrossRef]

69. Raven, B.H. The bases of power and the power/interaction model of interpersonal influence. Anal. Soc. Issues Public Policy 2008, 8, 1-22. [CrossRef]

70. Gradstein, M.; Justman, M. Human capital, social capital, and public schooling. Eur. Econ. Rev. 2000, 44, 879-890. [CrossRef]

71. Camilleri, M.A.; Camilleri, A.C. The Sustainable Development Goal on Quality Education. In The Future of the UN Sustainable Development Goals. CSR, Sustainability, Ethics \& Governance; Idowu, S., Schmidpeter, R., Zu, L., Eds.; Springer: Cham, Switzerland, 2020; pp. 261-277. [CrossRef]

72. Sutton, R.M.; Douglas, K.M. Justice for all, or just for me? More evidence of the importance of the self-other distinction in just-world beliefs. Personal. Individ. Diff. 2005, 39, 637-645. [CrossRef]

73. Brauer, M.; Bourhis, R.Y. Social power. Eur. J. Soc. Psychol. 2006, 36, 601-616. [CrossRef]

74. Cervone, C.; Augoustinos, M.; Maass, A. The Language of Derogation and Hate: Functions, Consequences, and Reappropriation. J. Lang. Soc. Psychol. 2021, 40, 80-101. [CrossRef]

75. Reicher, S.; Haslam, S.A.; Rath, R. Making a Virtue of Evil: A Five-Step Social Identity Model of the Development of Collective Hate. Soc. Personal. Psychol. Comp. 2008, 2, 1313-1344. [CrossRef]

76. Case, K.A.; Iuzzini, J.; Hopkins, M. Systems of Privilege: Intersections, Awareness, and Applications. J. Soc. Issues 2012, 68, 1-10. [CrossRef]

77. Bègue, L.; Bastounis, M. Two spheres of belief in justice: Extensive support for the bidimensional model of belief in a just world. J. Personal. 2003, 71, 435-463. [CrossRef]

78. Chen, S.; Shechter, D.; Chaiken, S. Getting at the truth or getting along: Accuracy- versus impression-motivated heuristic and systematic processing. J. Personal. Soc. Psychol. 1996, 71, 262-275. [CrossRef]

79. Proudfoot, D.; Fath, S. Signaling Creative Genius: How Perceived Social Connectedness Influences Judgments of Creative Potential. Personal. Soc. Psychol. Bull. 2021, 47, 580-592. [CrossRef] [PubMed]

80. Boyer, S.L.; Edmondson, D.R.; Artis, A.B.; Fleming, D. Self-Directed Learning: A Tool for Lifelong Learning. J. Mark. Educ. 2014, 36, 20-32. [CrossRef]

81. Knowles, M. Self-Directed Learning: A Guide for Learners and Teachers; Association Press: New York, NY, USA, $1975 ;$ p. 18.

82. Schweder, S. Mastery goals, positive emotions and learning behavior in self-directed vs. teacher-directed learning. Eur. J. Psychol. Educ. 2020, 35, 205-223. [CrossRef]

83. Neville, F.G.; Templeton, A.; Smith, J.R.; Louis, W.R. Social norms, social identities and the COVID-19 pandemic: Theory and recommendations. Soc. Personal. Psychol. Comp. 2021, 15, e12596. [CrossRef] [PubMed]

84. Packer, D.J.; Ungson, N.D.; Marsh, J.K. Conformity and reactions to deviance in the time of COVID-19. Group Process. Intergroup Relat. 2021, 24, 311-317. [CrossRef]

85. Harris, A. COVID-19-school leadership in crisis? J. Prof. Cap. Community 2020, 5, 321-326. [CrossRef]

86. Crompton, H.; Burke, D.; Jordan, K.; Wilson, S.W.G. Learning with technology during emergencies: A systematic review of K-12 education. Br. J. Educ. Technol. 2021, 52, 1554-1575. [CrossRef]

87. UNESCO. School Closures Caused by Coronavirus (COVID-19). Available online: en.unesco.org (accessed on 24 August 2021).

88. Kuhfeld, M.; Soland, J.; Tarasawa, B.; Johnson, A.; Ruzek, E.; Liu, J. Projecting the Potential Impact of COVID-19 School Closures on Academic Achievement. Educ. Res. 2020, 49, 549-565. [CrossRef]

89. Masonbrink, A.R.; Hurley, E. Advocating for Children During the COVID-19 School Closures. Pediatrics 2020, 146, e20201440. [CrossRef] 
90. Hidayati, A.N.; Ramalia, T.; Abdullah, F. Leveraging Skype-Based Webinars as An English Language Learning Platform. AL-ISHLAH J. Pendidik. 2021, 13, 10-20. [CrossRef]

91. Sangeeta, G.; Tandon, U. Factors influencing adoption of online teaching by school teachers: A study during COVID-19 pandemic. J. Public Aff. 2020, e2503. [CrossRef] [PubMed]

92. Pal, D.; Vanijja, V.; Patra, S. Online Learning During COVID-19: Students' Perception of Multimedia Quality. In Proceedings of the International Conference on Advances in Information Technology (IAIT2020), Bangkok, Thailand, 1-3 July 2020; ACM: New York, NY, USA, 2020. [CrossRef]

93. Kristóf, Z. International trends of remote teaching ordered in light of the coronavirus (COVID-19) and its most popular video conferencing applications that implement communication. Cent. Eur. J. Educ. Res. 2020, 2, 84-92. [CrossRef]

94. Basilaia, G.; Kvavadze, D. Transition to Online Education in Schools during a SARS-CoV-2 Coronavirus (COVID-19) Pandemic in Georgia. Pedagog. Res. 2020, 5, em0060. [CrossRef]

95. Pal, D.; Vanijja, V. Perceived usability evaluation of Microsoft Teams as an online learning platform during COVID-19 using system usability scale and technology acceptance model in India. Child. Youth Serv. Rev. 2020, 119, 105535. [CrossRef] [PubMed]

96. Martin, B.A. Teachers Perceptions of Google Classroom: Revealing Urgency for Teacher Professional Learning. Can. J. Learn. Technol. 2021, 47, 1-16. Available online: https://cjlt.ca/index.php/cjlt/article/view/27873/20526 (accessed on 15 November 2021). [CrossRef]

97. Nash, C. Report on Digital Literacy in Academic Meetings during the 2020 COVID-19 Lockdown. Challenges 2020, 11, 20. [CrossRef]

98. Serhan, D. Transitioning from face-to-face to remote learning: Students' attitudes and perceptions of using Zoom during COVID-19 pandemic. Int. J. Technol. Educ. Sci. 2020, 4, 335-342. [CrossRef]

99. Bin Rosawi, K.A. Zoom User Guide. Int. J. TESOL Stud. 2020, 2, 174-183. Available online: https:/ /link.gale.com/apps/doc/A6 33468251/AONE? u=anon $\{$ c0379e70\&sid=bookmark-AONE\&xid=6787f3ba (accessed on 15 November 2021).

100. Sutterlin, J. Learning is Social with Zoom Video Conferencing in your Classroom. ELearn 2018, 12, 5. [CrossRef]

101. Burgoyne, N.; Cohn, A.S. Lessons from the Transition to Relational Teletherapy During COVID-19. Fam. Process. 2020, 59, 974-988. [CrossRef] [PubMed]

102. Vinayak, S.P. 9 Ways to Keep Your Zoom Meetings Safe and Secure. 2020. Available online: https://www.problogbooster.com/20 20/03/zoom-app-is-safe-or-not-best-practices-for-securing-your-video-conference-meetings-privacy-mobile-user-accounts. html (accessed on 25 August 2021).

103. Reich, J.; Buttimer, C.; Coleman, D.; Colwell, R.; Faruqui, F.; Larke, L. What's Lost, What's Left, What's Next: Lessons Learned from the Lived Experiences of Teachers during the 2020 Novel Coronavirus Pandemic. edarXiv 2020, 1-28. [CrossRef]

104. Gupta, R.; Aggarwal, A.; Sable, D.; Chahar, P.; Sharma, A.; Kumari, A.; Maji, R. COVID-19 Pandemic and Online Education: Impact on Students, Parents and Teachers. J. Hum. Behav. Soc. Environ. 2021, 1-24. [CrossRef]

105. Grooms, A.A.; Childs, J. We Need to Do Better by Kids: Changing Routines in U.S. Schools in Response to COVID-19 School Closures. JESPAR 2021, 26, 135-156. [CrossRef]

106. Gasser, L.; Grütter, J.; Torchetti, L. Inclusive classroom norms, children's sympathy, and intended inclusion toward students with hyperactive behavior. J. Sch. Psychol. 2018, 71, 72-84. [CrossRef] [PubMed]

107. Arango, A.; Cole-Lewis, Y.; Lindsay, R.; Yeguez, C.E.; Clark, M.; King, C. The Protective Role of Connectedness on Depression and Suicidal Ideation Among Bully Victimized Youth. J. Clin. Child Adolesc. Psychol. 2019, 48, 728-739. [CrossRef] [PubMed]

108. Ambrose, A.J.H. Inequities During COVID-19. Pediatrics 2020, 146, e20201501. [CrossRef] [PubMed]

109. Russell, D.A. Positive aspects of teaching online during COVID-19: Zoom backgrounds, MannyCam, and increased student engagement. Proc. Mtgs. Acoust. 2021, 43, 025001. [CrossRef]

110. Castelli, F.R.; Sarvary, M.A. Why students do not turn on their video cameras during online classes and an equitable and inclusive plan to encourage them to do so. Ecol. Evol. 2021, 11, 3565-3576. [CrossRef] [PubMed]

111. Fortuna, L.R.; Tolou-Shams, M.; Robles-Ramamurthy, B.; Porche, M.V. Inequity and the disproportionate impact of COVID-19 on communities of color in the united states: The need for a trauma-informed social justice response. Psychol. Trauma Theory Res. Pract. Policy 2020, 12, 443-445. [CrossRef]

112. Borrero, N.E.; Yeh, C.J.; Cruz, C.I.; Suda, J.F. School as a Context for "Othering" Youth and Promoting Cultural Assets. Teach. Coll. Rec. 2012, 114, 1-37. Available online: https://www.tcrecord.org/books/Content.asp?ContentID=16246 (accessed on 15 November 2021). [CrossRef]

113. Nissenbaum, H. Privacy in Context: Technology, Policy, and the Integrity of Social Life; Stanford University Press: Palo Alto, CA, USA, 2010.

114. Steeves, V.; Regan, P. Young people online and the social value of privacy. J. Inf. Commun. Ethics Soc. 2014, 12, 298-313. [CrossRef]

115. Correia, A.-P.; Liu, C.; Xu, F. Evaluating videoconferencing systems for the quality of the educational experience. Distance Educ. 2020, 41, 429-452. [CrossRef]

116. Develotte, C.; Guichon, N.; Vincent, C. The use of the webcam for teaching a foreign language in a desktop videoconferencing environment. ReCALL 2010, 22, 293312. [CrossRef]

117. Kozar, O. Perceptions of webcam use by experienced online teachers and learners: A seeming disconnect between research and practice. Comput. Assist. Lang. Learn. 2016, 29, 779-789. [CrossRef]

118. Telles, J.A. Do we really need a webcam? The uses that foreign language students make out of webcam images during teletandem sessions. Let. Let. 2009, 25, 65-79. 
119. Baudson, T.G.; Weber, K.E.; Freund, P.A. More Than Only Skin Deep: Appearance Self-Concept Predicts Most of Secondary School Students' Self-Esteem. Front. Psychol. 2016, 7, 1568. [CrossRef] [PubMed]

120. Ng, C.H. Communicative Language Teaching (CLT) through Synchronous Online Teaching in English Language Preservice Teacher Education. Int. J. TESOL Stud. 2020, 2, 62-73. [CrossRef]

121. Rannastu-Avalos, M.; Siiman, L.A. Challenges for Distance Learning and Online Collaboration in the Time of COVID-19: Interviews with Science Teachers. In Collaboration Technologies and Social Computing; Springer International Publishing: Cham, Switzerland, 2020; pp. 128-142. [CrossRef]

122. Robertson, M.; Duffy, F.; Newman, E.; Prieto Bravo, C.; Ates, H.H.; Sharpe, H. Exploring changes in body image, eating and exercise during the COVID-19 lockdown: A UK survey. Appetite 2021, 159, 105062. [CrossRef] [PubMed]

123. Flannery, H.; Portnoy, S.; Daniildi, X.; Gedara, C.K.; Korchak, G.; Lambert, D.; McParland, J.; Payne, L.; Salvo, T.; Valentino, C.; et al. Keeping young people connected during COVID-19: The role of online groups. Arch. Dis. Child. 2021, 106, 739-744. [CrossRef]

124. O'Driscoll, D.; Taylor, L.K.; Dautel, J.B. Essentialist beliefs affect children's outgroup empathy, attitudes and prosocial behaviours in a setting of intergroup conflict. Int. J. Psychol. 2021, 56, 151-156. [CrossRef]

125. Kasser, T.; Koestner, R.; Lekes, N. Early Family Experiences and Adult Values: A 26-Year, Prospective Longitudinal Study. Personal. Soc. Psychol. Bull. 2002, 28, 826-835. [CrossRef]

126. Tenenbaum, H.R.; Winstone, N.E.; Leman, P.J.; Avery, R.E. How effective is peer learning? A meta-analysis. J. Educ. Psychol. 2020, 112, 1303-1319. [CrossRef]

127. Reynolds, K.J.; Subašić, E.; Tindall, K. The Problem of Behaviour Change: From Social Norms to an Ingroup Focus. Soc. Personal. Psychol. Compass 2015, 9, 45-56. [CrossRef]

128. Banerjee, R.; Watling, D.; Caputi, M. Peer relations and the understanding of faux pas: Longitudinal evidence for bidirectional associations. Child Dev. 2011, 82, 1887-1905. [CrossRef] [PubMed]

129. Kowal, J.; Fortier, M.S. Motivational determinants of flow: Contributions from self-determination theory. J. Soc. Psychol. 1999, 139, 355-368. [CrossRef]

130. Csikszentmihalyi, M. Flow: The Psychology of Optimal Experience; Harper \& Row: New York, NY, USA, 1990.

131. Csikszentmihalyi, M. Flow: The Psychology of Happiness; Random House: New York, NY, USA, 2013.

132. Deci, E.L.; Ryan, R.M. A motivational approach to self: Integration in personality. In Current Theory and Research in Motivation; Dienstbier, R., Ed.; University of Nebraska Press: Lincoln, NE, USA, 1991; Volume 38, pp. 237-288.

133. Elliot, A.J.; Hulleman, C.S. Achievment goals. In Handbook of Competence and Motivation: Theory and Application; Elliot, A.J., Dweck, C.S., Yeager, D.S., Eds.; Guilford: New York, NY, USA, 2017; pp. 43-60.

134. Endres, T.; Carpenter, S.; Martin, A.J.; Renkl, A. Enhancing learning by retrieval: Enriching free recall with elaborative prompting. Learn. Instr. 2017, 49, 13-20. [CrossRef]

135. Hulleman, C.S.; Barron, K.E. Motivation interventions in education. In Handbook of Educational Psychology, 3rd ed.; Corno, L., Anderman, E.M., Eds.; Routledge: New York, NY, USA, 2016; pp. 160-171.

136. Senko, C.; Dawson, B. Performance-Approach Goal Effects Depend on How They Are Defined: Meta-Analytic Evidence From Multiple Educational Outcomes. J. Educ. Psychol. 2017, 109, 574-598. [CrossRef]

137. Brookfield, S. Self-directed learning: A critical review of research. In New Directions for Adult and Continuing Education; Jossey-Bass: San Francisco, CA, USA, 1985; Volume 25, pp. 5-16. [CrossRef]

138. Wiklund, J.; Hatak, I.; Patzelt, H.; Shepherd, D. Mental disorders in the entrepreneurship context: When Being Different Can Be an Advantage. Acad. Manag. Personal. 2018, 32, 182-206. [CrossRef]

139. Nussbaumer-Streit, B.; Mayr, V.; Dobrescu, A.I.; Chapman, A.; Persad, E.; Klerings, I.; Wagner, G.; Siebert, U.; Christof, C.; Zachariah, C.; et al. Quarantine alone or in combination with other public health measures to control COVID-19: A rapid review. Cochrane Database Syst. Rev. 2020, 4, CD013574. [PubMed]

140. How COVID-19 Spreads. U.S. Centers for Disease Control and Prevention (CDC). 2020. Available online: https: / www.cdc.gov / coronavirus/2019-ncov/prevent-getting-sick/how-covid-spreads.html (accessed on 27 August 2021).

141. Palmer, C.; Peterson, R. Toxic Mask-ulinity: The Link between Masculine Toughness and Affective Reactions to Mask Wearing in the COVID-19 Era. Politics Gender 2020, 16, 1044-1051. [CrossRef]

142. Zhang, L.; Zhu, S.; Yao, H.; Li, M.; Si, G.; Tan, X. Study on Factors of People's Wearing Masks Based on Two Online Surveys: Cross-Sectional Evidence from China. Int. J. Environ. Res. Public Health 2021, 18, 3447. [CrossRef] [PubMed]

143. Haischer, M.H.; Beilfuss, R.; Hart, M.R.; Opielinski, L.; Wrucke, D.; Zirgaitis, G.; Uhrich, T.D.; Hunter, S.K. Who is wearing a mask? Gender-, age-, and location-related differences during the COVID-19 pandemic. PLoS ONE 2020, 15, e0240785. [CrossRef]

144. Eikenberry, S.E.; Mancuso, M.; Iboi, E.; Phan, T.; Eikenberry, K.; Kuang, Y.; Kostelich, E.; Gumel, A.B. To mask or not to mask: Modeling the potential for face mask use by the general public to curtail the COVID-19 pandemic. Infect. Dis. Model. 2020, 5, 293-308. [CrossRef] [PubMed]

145. Goh, Y.; Tan, B.Y.; Bhartendu, C.; Ong, J.J.; Sharma, V.K. The face mask: How a real protection becomes a psychological symbol during Covid-19? Brain Behav. Immun. 2020, 88, 1-5. [CrossRef]

146. Leitch, R. Masks as self-study. Challenging and sustaining teachers' personal and professional personae in early-mid career life phases. Teach. Teach. 2010, 16, 329-352. [CrossRef] 
147. Wilson, A.M.; Abney, S.E.; King, M.F.; Weir, M.H.; López-García, M.; Sexton, J.D.; Dancer, S.J.; Proctor, J.; Noakes, C.J.; Reynolds, K.A. COVID-19 and use of non-traditional masks: How do various materials compare in reducing the risk of infection for mask wearers? J. Hosp. Infect. 2020, 105, 640-642. [CrossRef] [PubMed]

148. Udwadia, Z.F.; Raju, R.S. The N-95 mask: Invaluable ally in the battle against the COVID-19 pandemic. Lung India Off. Organ Indian Chest Soc. 2020, 37, 323-328. [CrossRef]

149. McCauley, L.; Hayes, R. Taking responsibility for front-line health-care workers. Lancet 2020, 5, e461-e462. [CrossRef]

150. Chen, X.; Ran, L.; Liu, Q.; Hu, Q.; Du, X.; Tan, X. Hand Hygiene, Mask-Wearing Behaviors and Its Associated Factors during the COVID-19 Epidemic: A Cross-Sectional Study among Primary School Students in Wuhan, China. Int. J. Environ. Res. Public Health 2020, 17, 2893. [CrossRef] [PubMed]

151. Rieger, M.O. To wear or not to wear? Factors influencing wearing face masks in Germany during the COVID-19 pandemic. Soc. Health Behav. 2020, 3, 50-54. [CrossRef]

152. Ma, Y.; Zhan, N. To mask or not to mask amid the COVID-19 pandemic: How Chinese students in America experience and cope with stigma. Chin. Soc. Rev. 2020, 1-26. [CrossRef]

153. Boykin, K.; Brown, M.; Macchione, A.L.; Drea, K.M.; Sacco, D.F. Noncompliance with Masking as a Coalitional Signal to US Conservatives in a Pandemic. Evol. Psychol. Sci. 2021, 7, 232-238. [CrossRef]

154. Choi, S. People look at me like I AM the virus: Fear, stigma, and discrimination during the COVID-19 pandemic. Qual. Soc. Work. 2021, 20, 233-239. [CrossRef] [PubMed]

155. Grahlow, M.; Rupp, C.; Dernt, B. The Impact of Face Masks on Emotion Recognition Performance and Perception of Threat. Available online: Psyarxiv.com/6msz8 (accessed on 27 August 2021).

156. Faria, S.F.S.; Costa, F.O.; Pereira, A.G.; Cota, L.O.M. Self-perceived and self-reported breath odour and the wearing of face masks during the COVID-19 pandemic. Oral Dis. 2021, 1-11. [CrossRef] [PubMed]

157. Eli, I.; Baht, R.; Koriat, H.; Rosenberg, M. Self-perception of breath odor. J. Am. Dent. Assoc. 2021, 132, 621-626. [CrossRef] [PubMed]

158. Patel, J.; Kulkarni, S.; Doshi, D.; Reddy, P.; Reddy, S.; Srilatha, A. Association between social anxiety with oral hygiene status and tongue coating among patients with subjective halitosis. J. Dent. Hyg. 2017, 91, 55-63. [PubMed]

159. Xerfan, E.M.S.; Facina, A.S.; Andersen, M.L.; Tufik, S.; Tomimori, J. Acne flare-up due to mask wearing: A current pandemic scenario and its relationship with sleep. Skin. Res. Technol. 2021, 27, 1002-1003. [CrossRef] [PubMed]

160. Krolo, I.; Blazeka, M.; Merdzo, I.; Vrtar, I.; Sabol, I.; Vickovic, I. Mask-Associated Dry Eye During COVID-19 Pandemic-How Face Masks Contribute to Dry Eye Disease Symptoms. Med Arch. 2021, 75, 144-148. [CrossRef] [PubMed]

161. Boccardo, L. Self-reported symptoms of mask-associated dry eye: A survey study of 3,605 people. Contact Lens Anterior Eye 2021, 101408. [CrossRef]

162. Ribeiro, V.V.; Dassie-Leite, A.P.; Pereira, E.C.; Santos, A.D.N.; Martins, P.; de Alencar Irineu, R. Effect of Wearing a Face Mask on Vocal Self-Perception during a Pandemic. J. Voice 2020. [CrossRef] [PubMed]

163. Caniato, M.; Marzi, A.; Gasparella, A. How much COVID-19 face protections influence speech intelligibility in classrooms? Appl. Acoust. 2021, 178, 108051. [CrossRef]

164. Nobrega, M.; Opice, R.; Lauletta, M.M.; Nobrega, C.A. How face masks can affect school performance. Int. J. Pediatr. Otorhinolaryngol. 2020, 138, 110328. [CrossRef]

165. Saunders, G.H.; Jackson, I.R.; Visram, A.S. Impacts of face coverings on communication: An indirect impact of COVID-19. Int. J. Audiol. 2021, 60, 495-506. [CrossRef]

166. Shaw, K.; Butcher, S.; Ko, J.; Zello, G.A.; Chilibeck, P.D. Wearing of Cloth or Disposable Surgical Face Masks has no Effect on Vigorous Exercise Performance in Healthy Individuals. Int. J. Environ. Res. Public Health 2020, 17, 8110. [CrossRef]

167. Vance, D.; Shah, P.; Sataloff, R.T. COVID-19: Impact on the Musician and Returning to Singing; A Literature Review. J. Voice 2021. [CrossRef] [PubMed]

168. Gilmour, A. Let's talk about webcams, and a pedagogy of kindness. Compass J. Learn. Teach. 2021, 14, 1. [CrossRef]

169. Mento, C.; Lombardo, C.; Milazzo, M.; Whithorn, N.I.; Boronat-Catalá, M.; Almiñana-Pastor, P.J.; Fernàndez, C.S.; Bruno, A.; Muscatello, M.R.A.; Zoccali, R.A. Adolescence, Adulthood and Self-Perceived Halitosis: A Role of Psychological Factors. Medicina 2021, 57, 614. [CrossRef] [PubMed]

170. Broadhead, W.E.; Kaplan, B.H.; James, S.A.; Wagner, E.H.; Schoenbach, V.J.; Grimson, R.; Heyden, S.; Tibblin, G.; Gehlbach, S.H. The Epidemiologic Evidence For A Relationship Between Social Support And Health. Am. J. Epidemiol. 1983, 117, $521-537$. [CrossRef]

171. Harandi, T.F.; Taghinasab, M.M.; Nayeri, T.D. The correlation of social support with mental health: A meta-analysis. Electron. Physician 2017, 9, 5212-5222. [CrossRef]

172. Sani, F.; Elena, M.M.; Scrignaro, M.; McCollum, R. In-group identification mediates the effects of subjective in-group status on mental health. Br. J. Soc. Psychol. 2010, 49, 883-893. [CrossRef] [PubMed]

173. Garber, M. Character: The History of a Cultural Obsession; Farrar, Straus, and Giroux: New York, NY, USA, 2020.

174. Loyens, S.M.; Magda, J.; Rikers, R.M. Self-Directed Learning in Problem-Based Learning and its Relationships with Self-Regulated Learning. Educ. Psychol. Rev. 2008, 20, 411-427. [CrossRef]

175. Gandomkar, R.; Sandars, J. Clearing the confusion about self-directed learning and self-regulated learning. Med. Teach. 2018, 40, 862-863. [CrossRef] 
176. Nash, C. Challenges Identifying and Stimulating Self-Directed Learning in Publicly Funded Programs. In The Digital Era of Education: Novel Teaching Strategies and Learning Approaches Designed for Modern Students; Nova Science Publishers: Hauppauge, NY, USA, 2020; pp. 259-300.

177. Mukhtar, K.; Javed, K.; Arooj, M.; Sethi, A. Advantages, Limitations and Recommendations for online learning during COVID-19 pandemic era. Pak. J. Med. Sci. 2020, 36, S27-S31. [CrossRef] [PubMed]

178. Morris, T.H. Meeting educational challenges of pre- and post-COVID-19 conditions through self-directed learning: Considering the contextual quality of educational experience necessary. Horizon 2021, 29, 52-61. [CrossRef]

179. Mardiah, R.; Anastasia, I. EFL Students Online Learning Experience During Pandemic. Adv. Soc. Sci. Educ. Hum. Res. 2020, 509, 580-585.

180. Chen, C.H.; Chen, K.Z.; Tsai, H.F. Did Self-Directed Learning Curriculum Guidelines Change Taiwanese High-School Students' Self-Directed Learning Readiness? Asia-Pac. Educ. Res. 2021, 1-8. [CrossRef]

181. Robinson, J.D.; Persky, A.M. Developing Self-Directed Learners. Am. J. Pharm. Educ. 2020, 84, 847512. [CrossRef]

182. Guglielmino, L.M. Development of the Self-Directed Learning Readiness Scale. Ph.D. Thesis, University of Georgia, Athens, GA, USA, 1977.

183. Long, H.B.; Agyekum, S.K. Guglielmino's Self-Directed Learning Readiness Scale: A Validation Study. High. Educ. 1983, 12, 77-87. [CrossRef]

184. Long, H.B. Item Analysis of Guglielmino's Self-Directed Learning Readiness Scale. Int. J. Life. Educ. 1987, 6, 331-336. [CrossRef]

185. Field, L. Guglielmino's Self-Directed Learning Readiness Scale: Should it Continue to Be Used? Adult Educ. Q. 1991, 41, 100-103. [CrossRef]

186. Hoban, J.D.; Lawson, S.R.; Mazmanian, P.E.; Best, A.M.; Seibel, H.R. The Self-Directed Learning Readiness Scale: A Factor Analysis Study. Med. Educ. 2005, 39, 370-379. [CrossRef] [PubMed]

187. Williams, B.; Brown, T. A Confirmatory Factor Analysis of the Self-Directed Learning Readiness Scale. Nurs. Health Sci. 2013, 15, 430-436. [CrossRef]

188. Hendry, G.; Ginns, P. Readiness for Self-Directed Learning: Validation of a New Scale with Medical Students. Med. Teach. 2009, 31, 918-920. [CrossRef]

189. Mohamad Nasri, N.; Nasri, N.; Asyraf Abd Talib, M. The Unsung Role of Assessment and Feedback in Self-Directed Learning (SDL). J. Furth. High. Educ. 2021, 1-13. [CrossRef]

190. Sorokowska, A.; Sorokowski, P.; Hilpert, P.; Cantarero, K.; Frackowiak, T.; Ahmadi, K.; Alghraibeh, A.M.; Aryeetey, R.; Bertoni, A.; Bettache, K.; et al. Preferred Interpersonal Distances: A Global Comparison. J. Cross-Cult. Psychol. 2017, 48, 577-592. [CrossRef]

191. Davy, B. Social Distancing and Cultural Bias. J. Am. Plan. Assoc. 2021, 87, 159-166. [CrossRef]

192. Bar-Tal, D.; Vered, S.; Fuxman, S. Between Open-minded Critical Thinking and Closed-minded Allegiance: Educational Tensions in Societies Involved in Intractable Conflict. Political Psychol. 2020, 1-26. [CrossRef]

193. Abrams, D.; Hogg, M.A. Social Identification, Self-Categorization and Social Influence. Eur. Rev. Soc. Psychol. 1990, 1, 195-228. [CrossRef]

194. Haste, H. Constructing the Citizen. Pol. Psychol. 2004, 25, 413-439. [CrossRef]

195. Seltzer, K. Engaging Students in Virtual Instruction with the Camera Off. Edutopia. 2020. Available online: https://www. edutopia.org/article/engaging-students-virtual-instruction-camera (accessed on 3 September 2021).

196. Marsh, S. The Eyes Don't Have It: Masks Upset Classroom Communication. AP News. 2020. Available online: https://apnews. com/article/virus-outbreak-us-news-ap-top-news-featured-in-state-wire-52b44eed118bc03579c41795637e9b86 (accessed on 3 September 2021).

197. Park, A. Wearing Face Masks and Social Distancing Actually Work to Contain COVID-19, According to a New Study. Time. 2020. Available online: https:/ / time.com/5846288/social-distancing-face-masks-covid/ (accessed on 3 September 2021).

198. Reny, T.T.; Barreto, M.A. Xenophobia in the time of pandemic: Othering, anti-Asian attitudes, and COVID-19. Polit. Groups Identities 2020, 1-24. [CrossRef]

199. Ye, J. Pediatric Mental and Behavioral Health in the Period of Quarantine and Social Distancing With COVID-19. JMIR Pediatr Parent. 2020, 3, e19867. [CrossRef] [PubMed]

200. O'Connor, D.B.; Aggleton, J.P.; Chakrabarti, B.; Cooper, C.L.; Creswell, C.; Dunsmuir, S.; Fiske, S.T.; Gathercole, S.; Gough, B.; Ireland, J.L.; et al. Research priorities for the COVID-19 pandemic and beyond: A call to action for psychological science. Br. J. Psychol. 2020, 111, 603-629. [CrossRef]

201. Gilic, B.; Ostojic, L.; Corluka, M.; Volaric, T.; Sekulic, D. Contextualizing Parental/Familial Influence on Physical Activity in Adolescents before and during COVID-19 Pandemic: A Prospective Analysis. Children 2020, 7, 125. [CrossRef]

202. Weis, R.; Ray, S.D.; Cohen, T.A. Mindfulness as a way to cope with COVID-19-related stress and anxiety. Couns. Psychother. Res. 2021, 21, 8-18. [CrossRef]

203. Kaufman, M.R.; Wright, K.; Simon, J.; Edwards, G.; Thrul, J.; DuBois, D.L. Mentoring in the Time of COVID-19: An Analysis of Online Focus Groups with Mentors to Youth. Am. J. Community Psychol. 2021, 1-13. [CrossRef] [PubMed]

204. Van Esch, C.; Luse, W.; Bonner, R.L. The impact of COVID-19 pandemic concerns and gender on mentor seeking behavior and self-efficacy. Equal. Divers. Incl. Int. J. 2021. [CrossRef]

205. Clark, A.E.; Nong, H.; Zhu, H.; Zhu, R. Compensating for academic loss: Online learning and student performance during the COVID-19 pandemic. China Econ. Rev. 2021, 68, 101629. [CrossRef] 
206. Squire, K.D. From virtual to participatory learning with technology during COVID-19. E-Learn. Digit. Media 2021, 20427530211022926. [CrossRef]

207. Yi, H.; Pingsterhaus, A.; Song, W. Effects of Wearing Face Masks While Using Different Speaking Styles in Noise on Speech Intelligibility During the COVID-19 Pandemic. Front. Psychol. 2021, 12, 682677. [CrossRef] [PubMed]

208. Swaminathan, D.; Meera, S.S. Masks Mask Communication-Communicating with Children in Health Care Settings. Indian J. Pediatr. 2021, 88, 283-284. [CrossRef] [PubMed]

209. Achanta, S.; Sasidharan, S.; Majji, D.; Uppala, D. “Mask Mouth" During COVID-19 Pandemic-A Myth or A Truth. IJMADR 2021, 1, 56-63. Available online: https:/ / www.ijmadr.com/view-article/23 (accessed on 15 November 2021).

210. Adams, M.; Bell, L.A.; Griffin, P. Teaching for Diversity and Social Justice, 2nd ed.; Routledge: New York, NY, USA, 2007.

211. Brammer, S.; Branicki, L.; Linnenluecke, M.K. COVID-19, Societalization, and the Future of Business in Society. Acad. Manag. Perspect. 2020, 34, 493-507. [CrossRef]

212. Pereda, N.; Díaz-Faes, D.A. Family violence against children in the wake of COVID-19 pandemic: A review of current perspectives and risk factors. Child Adolesc. Psychiatry Ment. Health 2020, 14, 40. [CrossRef] [PubMed]

213. Pyszczynski, T.; Lockett, M.; Greenberg, J.; Solomon, S. Terror Management Theory and the COVID-19 Pandemic. J. Human. Psychol. 2021, 61, 173-189. [CrossRef]

214. Levy, S.; Mason, S.; Russon, J.; Diamond, G. Attachment-based family therapy in the age of telehealth and COVID-19. J. Marital Fam. Ther. 2021, 47, 440-454. [CrossRef] [PubMed]

215. Gray, P.; Riley, G. Grown Unschoolersâ€ $€^{\mathrm{TM}}$ Evaluations of Their Unschooling Experiences: Report I on a Survey of 75 Unschooled Adults Authors. Other Educ. 2015, 4, 8-32.

216. Gray, P.; Riley, G. Grown Unschoolersâ€ ${ }^{\mathrm{TM}}$ Evaluations of Their Unschooling Experiences: Report II on a Survey of 75 Unschooled Adults Authors. Other Educ. 2015, 4, 33-53. 